\title{
Pengaruh Sarana Belajar Terhadap Prestasi Belajar Siswa Sekolah Dasar
}

\author{
Sitirahayu ${ }^{1}$, Heru Purnomo² \\ Universitas PGRI Yogyakarta \\ E-mail: rsiti3465@gmail.com,user1@upy.ac.id
}

\begin{tabular}{|c|c|}
\hline Article Info & Abstract \\
\hline $\begin{array}{l}\text { Article History } \\
\text { Received: } 2021-03-02 \\
\text { Revised: 2021-06-10 } \\
\text { Published: } 2021-06-17\end{array}$ & $\begin{array}{l}\text { This study aims to determine how much influence learning facilities have on student } \\
\text { achievement. This study uses a literature review, which is a research methodology that } \\
\text { aims to collect and extract the essence of previous research and analyze several } \\
\text { overviews of experts written in the text. The results of this study can be concluded that } \\
\text { learning facilities are a factor that can improve student achievement. Because the more } \\
\text { complete the learning facilities they have, the students can learn well. Facilitate, } \\
\text { accelerate, and deepen students in the independent learning process. With the } \\
\text { independent learning process, student learning achievement will be obtained } \\
\text { maximally, for that learning facilities are needed to achieve student achievement. }\end{array}$ \\
\hline Artikel Info & Abstrak \\
\hline $\begin{array}{l}\text { Sejarah Artikel } \\
\text { Diterima: } 2021-06-02 \\
\text { Direvisi: } 2021-06-10 \\
\text { Dipublikasi: } 2021-06-17\end{array}$ & $\begin{array}{l}\text { Penelitian ini bertujuan untuk mengetahui seberapa besar pengaruh sarana belajar } \\
\text { terhadap prestasi belajar siswa. Penelitian ini menggunakan tinjauan pustaka, yaitu } \\
\text { suatu metodologi penelitian yang bertujuan untuk mengumpulkan dan mengekstrak } \\
\text { intisari penelitian sebelumnya dan menganalisis beberapa gambaran umum para ahli } \\
\text { yang tertulis dalam teks. Hasil penelitian ini dapat disimpulkan bahwa fasilitas belajar } \\
\text { merupakan faktor yang dapat meningkatkan prestasi belajar siswa. Karena semakin } \\
\text { lengkap fasilitas belajar yang dimiliki, maka siswa dapat belajar dengan baik. } \\
\text { Memfasilitasi, mempercepat, dan memperdalam siswa dalam proses belajar mandiri. } \\
\text { Dengan adanya proses belajar mandiri maka prestasi belajar siswa akan diperoleh } \\
\text { secara maksimal, untuk itu diperlukan fasilitas belajar untuk mencapai prestasi belajar } \\
\text { siswa }\end{array}$ \\
\hline
\end{tabular}

\section{PENDAHULUAN}

Pendidikan memegang peranan yang sangat penting dalam menciptakan peserta didik yang unggul dan memiliki kualitas sumber daya manusia (SDM) yang berkualitas dan bermanfaat bagi banyak orang nantinya. Peningkatan sumber daya manusia merupakan langkah terpenting yang harus dilakukan dalam dunia pendidikan. Sumber daya manusia yang berkualitas dan potensial dalam arti luas yang diciptakan oleh dunia pendidikan akan membentuk sumber daya manusia tersebut dalam rangka merespon perubahan global yang akan mempengaruhi kehidupan bermasyarakat, berbangsa dan bernegara. Berhasil tidaknya dunia pendidikan dalam menciptakan sumber daya manusia yang berkualitas dan berpotensi salah satunya dipengaruhi oleh mutu pendidikan melalui pembinaan dan pengarahan peserta didik agar menjadi manusia yang berakhlak mulia dan mampu berkembang dengan baik sesuai dengan kemampuan dan kemampuannya. bakat yang ada pada anak. Dalam mewujudkan tingkat pendidikan yang berkualitas, program pembelajaran sangat berpengaruh terhadap prestasi belajar seseorang. Pendidikan yang berkualitas akan mampu menghasilkan peserta didik yang berprestasi dan juga sumber daya manusia yang berkualitas. Untuk mencapai peningkatan mutu pendidikan, salah satunya harus didukung oleh fasilitas belajar yang memadai dan lingkungan belajar yang efektif.

Fasilitas belajar merupakan sarana belajar yang diperlukan dalam proses pembelajaran agar pencapaian tujuan pembelajaran dapat berjalan dengan lancar, teratur, efektif dan efisien (Roestiyah, 2004: 166). Kemudian menurut Mulyata (2002:49) sarana atau fasilitas belajar adalah peralatan dan perlengkapan yang langsung digunakan dalam menunjang proses belajar mengajar seperti gedung, ruang kelas, meja, kursi, dan alat media pembelajaran. Poerwanto (2007) memberikan pengertian tentang prestasi belajar, yaitu "hasil yang dicapai seseorang dalam upaya belajar sebagaimana tercantum dalam rapor". Selanjutnya Winkel (1997) mengatakan bahwa "prestasi belajar merupakan bukti keberhasilan belajar atau kemampuan seorang siswa untuk melaksanakan kegiatan belajar sesuai dengan bobot yang dicapai", Fasilitas belajar sangat berpengaruh terhadap perkembangan belajar anak. Sarana belajar yang dimaksud adalah alat-alat yang digunakan siswa dalam membantu proses pembelajaran seperti ruang belajar, suasana belajar, alat belajar, penerangan. Fasilitas belajar berpengaruh terhadap prestasi 
belajar siswa. Karena semakin lengkap fasilitas belajar yang dimiliki, maka siswa dapat belajar dengan baik. Memfasilitasi, mempercepat, dan memperdalam siswa dalam proses belajar mandiri. Dengan adanya proses belajar mandiri maka prestasi belajar siswa akan diperoleh secara maksimal, untuk itu diperlukan fasilitas belajar untuk mencapai prestasi belajar siswa. Tujuan dari penelitian ini adalah untuk mengetahui seberapa besar pengaruh sarana belajar terhadap prestasi belajar siswa sekolah dasar.

\section{METODE PENELITIAN}

Metodologi penelitian ini menggunakan literature review, peneliti memilih literature review sebagai metode dalam penulisan ini. Hal ini didasarkan pada tujuan penulisan yang ingin menganalisis pengaruh sarana belajar terhadap prestasi belajar siswa sekolah dasar, dengan tinjauan pustaka akan diperoleh penjelasan dari beberapa ahli (melalui tulisan) tentang pengertian sarana belajar dan hubungannya. terhadap prestasi siswa sekolah dasar. Menurut Snyder (2019:333), tinjauan pustaka adalah metodologi penelitian yang bertujuan untuk mengumpulkan dan mengambil intisari dari penelitian sebelumnya dan menganalisis beberapa tinjauan ahli yang tertulis dalam teks. Snyder (2019:339) menyimpulkan bahwa literature review berperan sebagai landasan bagi berbagai jenis penelitian karena hasil dari literature review memberikan pemahaman tentang perkembangan pengetahuan, sumber stimulus untuk pembuatan kebijakan, memicu penciptaan baru gagasan dan berguna sebagai pedoman untuk penelitian di bidang tertentu. Penelitian ini dilakukan untuk menguji teori yang berkaitan dengan pengaruh sarana belajar terhadap prestasi belajar siswa sekolah dasar. Penulis membaca kemudian mencatat dan memahami, menganalisis, dan membandingkan satu atau hal-hal yang berkaitan dengan pengaruh fasilitas belajar terhadap prestasi belajar siswa sekolah dasar.

\section{HASIL DAN PEMBAHASAN}

\section{A. Sarana Belajar}

Fasilitas belajar merupakan sarana belajar yang diperlukan dalam proses pembelajaran agar pencapaian tujuan pembelajaran dapat berjalan dengan lancar, teratur, efektif dan efisien (Roestiyah, 2004: 166). Menurut Peraturan Menteri Pendidikan Nasional Nomor 40 Tahun 2008 Sarana adalah perlengkapan belajar yang dapat dipindah-pindahkan. Secara umum sarana dan prasarana merupakan peralatan yang menunjang keberhasilan suatu proses yang dilakukan dalam rangka mencapai suatu tujuan tertentu. Kemudian menurut Mulyata (2002: 49) fasilitas belajar adalah peralatan dan perlengkapan yang langsung digunakan dalam menunjang proses belajar mengajar seperti gedung, ruang kelas, meja, kursi, dan alat media pembelajaran. Menurut Bafadal (2014:2) sarana pendidikan adalah semua perlengkapan, bahan dan perabot yang langsung digunakan dalam proses pendidikan di sekolah, sedangkan prasarana adalah segala perlengkapan pokok yang secara tidak langsung mendukung terselenggaranya proses pendidikan di sekolah. Dan yang terakhir, menurut Sanjaya (2009:55) mengungkapkan pengertian fasilitas adalah segala sesuatu yang berhubungan langsung dengan siswa dan menunjang kelancaran dan keberhasilan proses belajar siswa yang meliputi media pembelajaran, alat belajar, perlengkapan sekolah dan lainlain. Selain pengertian fasilitas belajar sebagaimana tersebut di atas, fasilitas belajar juga memiliki indikator yang menurut Dimyaiti dan Mudjiono (2009: 17) terdiri dari :

1) Sarana: 1) media pembelajaran, 2) perangkat pembelajaran meliputi: buku teks, buku bacaan, alat praktikum, alat tulis, dan lain-lain. 3) Perlengkapan sekolah meliputi: ruang kelas, lapangan olah raga, ruang ibadah, ruang kesenian, perlengkapan olah raga, perpustakaan, dan laboratorium.

2) Prasarana: 1) Jalan menuju sekolah, 2) Penerangan.

Lebih lengkapnya, dalam kaitannya dengan belajar dan proses belajar mengajar, terdapat dua jenis sarana pendidikan, yaitu pertama, sarana pendidikan yang digunakan langsung dalam proses belajar mengajar, misalnya kapur tulis, atlas dan sarana pendidikan lainnya yang digunakan oleh guru. dalam mengajar. Kedua, sarana pendidikan yang secara tidak langsung berkaitan dengan proses belajar mengajar seperti lemari dan arsip sekolah yang merupakan sarana pendidikan yang secara tidak langsung digunakan oleh guru dalam proses belajar mengajar. Jika dilihat dari fungsi dan perannya dalam proses belajar mengajar, sarana pendidikan dapat dibedakan menjadi:

1) Alat belajar, alat belajar adalah alat yang digunakan secara langsung dalam proses belajar mengajar. Alat-alat tersebut dapat berupa buku catatan, gambar, alat tulis lainnya seperti kapur tulis, penghapus dan papan tulis serta alat-alat latihan yang kesemuanya termasuk dalam ruang lingkup alat pembelajaran.

2) Alat peraga, alat peraga memiliki arti yang luas. Alat peraga adalah semua alat peraga pendidikan dan pengajaran, yang dapat berupa benda atau tindakan dari tingkat yang paling konkrit sampai dengan yang paling abstrak yang dapat memudahkan pemberian pemahaman (penyampaian konsep) kepada peserta didik. Berdasarkan penggunaannya, alat peraga dapat dibedakan menjadi dua, yaitu: 1) Alat peraga langsung, yaitu jika guru menjelaskan dengan menunjukkan benda yang sebenarnya (benda dibawa ke kelas, atau siswa diajak ke benda itu). 2) Alat peraga tidak langsung, yaitu jika guru menggantikan benda yang sebenarnya. Berturut-turut dari yang konkret ke abstrak, alat peraga tersebut dapat 
berupa benda buatan (miniatur), film, slide, foto, gambar, sketsa atau bagan. Selain pembagian ini, masih banyak lagi alat peraga atau peragaan berupa tindakan atau kegiatan yang dilakukan oleh guru

3) Media pengajaran, kata media berasal dari bahasa latin dan merupakan bentuk jamak dari kata medium yang secara harfiah berarti perantara atau pengantar. Media adalah segala alat yang dapat digunakan sebagai saluran pesan untuk mencapai tujuan pengajaran. Media adalah sesuatu yang menyalurkan pesan dan dapat merangsang pikiran, perasaan dan kemauan siswa sehingga dapat mendorong terjadinya proses belajar pada diri siswa. Oleh karena itu, penggunaan media secara kreatif akan memungkinkan siswa untuk belajar lebih baik dan dapat meningkatkan kinerjanya sesuai dengan tujuan yang ingin dicapai.

Semua pembelajaran memegang peranan yang sangat penting dalam menunjang pencapaian keberhasilan pembelajaran dengan penggunaan fasilitas pembelajaran yang sesuai dalam pembelajaran yang diharapkan dapat memberikan kemudahan dalam menyerap materi yang disajikan. Pemanfaatan fasilitas belajar yang tepat merupakan faktor yang harus diperhatikan dalam kegiatan pembelajaran, karena kegiatan pembelajaran akan berjalan dengan baik jika didukung oleh fasilitas belajar yang baik dan memadai, begitu pula sebaliknya jika tidak ada sarana dan prasarana yang baik menyebabkan siswa terhambat dalam belajar sehingga sehingga dapat mempengaruhi prestasi siswa. Menurut Slameto (1995:28) salah satu syarat keberhasilan belajar adalah belajar memerlukan sarana, fasilitas belajar atau fasilitas yang menunjang kegiatan belajar siswa.

Pasal 42 Peraturan Pemerintah Nomor 19 Tahun 2005 tentang Standar Nasional Pendidikan menyatakan bahwa (1). Setiap satuan pendidikan wajib memiliki fasilitas yang meliputi perabot, perlengkapan pendidikan, media pendidikan, buku dan sumber belajar lainnya, bahan habis pakai, dan perlengkapan lain yang diperlukan untuk mendukung proses pembelajaran yang tertib dan berkesinambungan. (2). Setiap satuan pendidikan wajib memiliki prasarana yang meliputi ruang kelas, ruang pimpinan satuan pendidikan, ruang pendidik, ruang administrasi, ruang perpustakaan, ruang laboratorium, ruang bengkel, ruang unit produksi, ruang kantin, instalasi listrik dan jasa, tempat latihan, tempat bekerja. ibadah, tempat bermain, tempat berkreasi, dan ruang/tempat lain yang diperlukan untuk mendukung proses pembelajaran yang tertib dan berkesinambungan

Sarana pendidikan dapat diklasifikasikan menjadi tiga jenis, yaitu berdasarkan habis atau tidaknya, berdasarkan bergerak atau tidaknya, dan berdasarkan hubungannya dengan proses pembelajaran. Dilihat dari habis tidaknya ada dua macam, yaitu sarana pendidikan yang habis pakai dan sarana pendidikan yang tahan lama. Jika dilihat dari bergerak atau tidak pada saat belajar ada dua macam yaitu bergerak atau tidak bergerak. Sedangkan jika dilihat dari hubungannya dengan proses pembelajaran, ada tiga macam perangkat pembelajaran, alat peraga, dan media pembelajaran. Menurut Arsyad (2006:25) penggunaan sarana belajar memberikan beberapa manfaat, yaitu: a). Pemanfaatan fasilitas pembelajaran dapat memperjelas pesan dan informasi sehingga memudahkan dan meningkatkan proses dan hasil pembelajaran. B). Meningkatkan dan menggairahkan perhatian anak sehingga dapat menimbulkan motivasi belajar, interaksi yang lebih langsung antara siswa dengan lingkungannya dan memungkinkan siswa untuk belajar sendiri sesuai dengan kemampuan dan minatnya. c). Memberikan siswa pengalaman umum tentang peristiwa di lingkungannya, dan memungkinkan interaksi langsung dengan guru, masyarakat dan lingkungannya, misalnya melalui karyawisata dan lain-lain, Pemanfaatan fasilitas belajar yang baik akan memudahkan anak dalam melakukan kegiatan belajar sehingga anak lebih semangat dalam belajar. Sebaliknya, kurangnya fasilitas belajar akan mengakibatkan anak menjadi kurang bersemangat dan kurang antusias dalam belajar. Hal ini tentunya akan mempengaruhi prestasi belajar anak.

\section{B. Prestasi Belajar}

Prestasi belajar adalah tingkat keberhasilan siswa dalam mempelajari materi pelajaran di sekolah yang dinyatakan dalam bentuk skor yang diperoleh dari hasil tes mengenai sejumlah mata pelajaran (Syah, 2009:42). Prestasi belajar dapat juga disebut kemampuan aktual (actual ability) yang diperoleh seseorang setelah belajar, suatu keterampilan potensial (potential ability), yaitu kemampuan dasar yang berupa disposisi yang dimiliki individu untuk mencapai prestasi. Keterampilan aktual dan keterampilan potensial dapat dimasukkan ke dalam istilah yang lebih umum, yaitu kemampuan (Yasa, 200: 14). Kemudian menurut Sevi (2008:28) prestasi belajar adalah hasil yang dicapai seorang siswa dalam upaya belajarnya yang dituangkan dalam nilai rapornya. Melalui prestasi belajar seorang siswa dapat mengetahui kemajuan yang telah dicapainya dalam belajar. Pengertian di atas dapat disimpulkan bahwa prestasi belajar dapat diartikan sebagai hasil atau nilai keterampilan yang dicapai siswa dari suatu usaha atau studi dalam jangka waktu tertentu yang dapat memberikan kepuasan bagi siswa

\section{Faktor yang mempengaruhi Prestasi Belajar}

Untuk mencapai prestasi belajar siswa seperti yang diharapkan, perlu memperhatikan beberapa faktor yang mempengaruhi prestasi belajar, antara 
lain faktor yang terdapat dalam diri siswa (faktor internal), dan faktor yang terdiri dari luar siswa (faktor eksternal). Faktor yang berasal dari dalam diri anak adalah fisiologis dan psikologis, sedangkan faktor yang berasal dari luar anak adalah faktor lingkungan, termasuk keluarga dan masyarakat. Lebih jelasnya diuraikan di bawah ini menurut Djamarah (2008: 149), yaitu:

1) Faktor Intern

Faktor intern adalah faktor yang timbul dari dalam diri individu itu sendiri. Adapun yang dapat digolongkan ke dalam faktor intern yaitu kecerdasan atau intelegensi, bakat, minat, motivasi, dan kemampuan kognitif, Faktor Intern terdiri atas Kecerdasan atau intelegensi, Bakat, Minat, Motivasi

2) Faktor Ekstern

Faktor ekstern merupakan faktor yang efektif dalam prestasi belajar yang terdapat di luar diri siswa yaitu berupa pengalaman, keadaan keluarga dan lingkungan sekitarnya. Akibat dari lingkungan ini kebanyakan bersifat positif dan tidak memberikan paksaan kepada individu, faktor ekstern yang dapat mempengaruhi belajar adalah keadaan keluarga, keadaan sekolah dan lingkungan masyarakat, Faktor Extern terdiri atas: Keadaan keluarga, Keadaan Sekolah, Lingkungan Masyarakat

Kebutuhan untuk berprestasi adalah dorongan untuk unggul, untuk unggul dalam kaitannya dengan seperangkat standar, untuk berjuang untuk sukses. Kebutuhan akan kekuasaan (need for power) adalah kebutuhan untuk membuat orang lain berperilaku sedemikian rupa sehingga orang tersebut tidak akan dipaksa untuk berperilaku atau suatu bentuk ekspresi individu untuk mengontrol dan mempengaruhi orang lain Kebutuhan untuk berafiliasi adalah keinginan untuk hubungan interpersonal yang ramah dan intim. Individu mencerminkan keinginan untuk menjalin hubungan yang erat, kooperatif dan bersahabat dengan pihak lain. Kelengkapan sarana dan prasarana pembelajaran yang dimiliki sekolah akan mendukung variasi dalam pengajaran. penggunaan sarana dan prasarana pembelajaran sangat diperlukan dalam menunjang keberhasilan proses pembelajaran, memilih dan menentukan sarana dan prasarana pembelajaran guna mendorong keinginan siswa agar termotivasi dalam belajar adalah tugas guru. Dengan adanya sarana dan prasarana yang memadai sesuai dengan standar sarana dan prasarana sekolah memungkinkan siswa termotivasi untuk belajar mengikuti pembelajaran yang pada akhirnya mampu meningkatkan hasil belajarnya.

\section{SIMPULAN DAN SARAN}

\section{A. Simpulan}

Sarana belajar sangat berpengaruh terhadap perkembangan belajar anak. Sarana belajar yang di maksud merupakan alat-alat yang digunakan siswa dalam membantu proses belajarnya seperti ruangan belajar, suasana tempat belajar, alat-alat pelajaran, penerangan. Sarana belajar sangat mempunyai pengaruh terhadap prestasi belajar siswa. Karena semakin lengkap sarana belajar yang dimiliki maka siswa dapat belajar dengan baik. Mempermudah, mempercepat, dan memperdalam siswa dalam proses belajar mandiri. Dengan proses belajar mandiri maka prestasi belajar siswa akan diperoleh secara maksimal, untuk itu fasilitas belajar sangat diperlukan untuk mencapai prestasi belajar siswa. Sarana pembelajaran menjadi faktor yang dapat meningkatkan prestasi belajar siswa. Semakin baiknya sarana pembelajaran disekolah tentu dapat meningkatkan hasil belajar yang dapat diinginkan.

\section{B. Saran}

Bagi sekolah perlunya menjaga hasil belajar siswa serta dapat meningkatkan hasil belajar bagi siswa yang nilainya dibawah standar sekolah. Sekolah juga perlu memperhatikan siswa-siswa dengan hasil belajar tinggi supaya dapat membantu temannya yang belum mencapai nilai tersebut. Serta perlunya peningkatan sarana pembelajaran yang dapat mendukung terhadap peningkatan hasil belajar serta peningkatan hubungan terhadap orang tua siswa apabila terjadi atau mengurangi masalah yang mungkin muncul terhadap siswa. Karena dari penelitian ini dapat disimpulkan bahwa sarana pembelajaran menjadi faktor yang dapat meningkatkan hasil belajar. Semakin baiknya sarana pembelajaran di sekolah tentu dapat meningkatkan hasil belajar yang dapat diinginkan. Sekolah juga perlu meningkatkan hubungan sekolah terhadap orang tua dimana orang tua berpartisipasi juga dalam perkembangan siswa saat di sekolah maupun dirumah, sedangkan bagi orang tua siswa perlu adanya kesiapan dalam pemenuhan sarana pembelajaran yang baik serta tercukupi. Orang tua siswa tentu menginginkan hasil belajar anaknya menjadi lebih baik dan hal tersebut dapat tercapai dengan pemenuhan sarana pembelajaran dimana hal tersebut berpengaruh besar terhadap hasil belajar siswa. Orang tua siswa juga perlu memperhatikan partisipasi bagi perkembangan belajar anaknya sehingga dapat mengetahui apabila anaknya mengalami masalah dalam belajar dan keberhasilan dalam mencapai hasil belajar. Orang tua juga perlu meningkatkan hubungan dengan sekolah untuk mengetahui perkembangan anak saat berada di sekolah sehingga dapat mencari solusi apabila anak mengalami kendala-kendala

\section{DAFTAR RUJUKAN}

Cintya, A. N. D., \& Nugraha, J. (2020). Pengaruh Sarana Prasarana dan Motivasi Belajar terhadap Hasil Belajar Siswa Kelas XII Otomatisasi Tata Kelola 
Perkantoran di SMK Ketintang Surabaya. Jurnal Pendidikan Administrasi Perkantoran (JPAP), 9(1), 1-16.

Cynthia, L. C., Martono, T., \& Indriayu, M. (2016). Pengaruh Fasilitas Belajar Dan Motivasi Belajar Terhadap Prestasi Belajar Mata Pelajaran Ekonomi Siswa Kelas XII IS Di SMA Negeri 5 Surakarta Tahun Ajaran 2015/2016. BISE: Jurnal Pendidikan Bisnis dan Ekonomi, 1(2)

Fatih Holis Ahnaf, Farida Rochmawati, Sri Maria Utami, \& Dini Dwi Syahputri. (2021). Efektivitas Media Animasi Audio Visual dalam Kuliah Daring Keterampilan Membaca. Ainara Journal (Jurnal Penelitian Dan PKM Bidang Ilmu Pendidikan), 2(2), 72-78. https://doi.org/10.1234567/ainarajournal.v2i $\underline{2.27}$

Hamdu, G., \& Agustina, L. (2011). Pengaruh motivasi belajar siswa terhadap prestasi belajar IPA di sekolah dasar. Jurnal penelitian pendidikan, 12(1), 90-96

Ilyas, K. K. (2018). Penggunaan Sarana Pembelajaran terhadap Prestasi Belajar Pendidikan Agama Islam Peserta didik Kelas XI SMA Negeri 3 Kabupaten Pinrang (Doctoral dissertation, IAIN Parepare)

Kristiyono, K. (2018). Pengaruh Sarana Pembelajaran Dan Partisipasi Orang Tua Terhadap Hasil Belajar Mata Pelajaran IPS. Ecodunamika, 1(3).
Legiwati, N. (2016). Pengaruh Pemanfaatan Sarana dan Prasarana Pembelajaran dan Motivasi Belajar terhadap Hasil Belajar Siswa Kelas VII SMPN 3 Grati Satap Kabupaten Pasuruan. Jurnal Penelitian dan Pendidikan IPS, 10(2), 294-309.

MAULIYA NUR CAHYANI, T. R. I. (2019). Pengaruh Sarana Prasarana Dan Kepemimpinan Kepala Sekolah Terhadap Prestasi Belajar Siswa Di SMK Farmasi Surabaya dan SMK Al-Irsyad Surabaya. Inspirasi Manajemen Pendidikan, $7(1)$

Nurislaminingsih, R., Rachmawati, T. S., \& Winoto, Y. (2020). Pustakawan Referensi Sebagai Knowledge Worker. Anuva: Jurnal Kajian Budaya, Perpustakaan, dan Informasi, 4(2), 169- 182

Puspitasari, W. D. (2016). Pengaruh Sarana Belajar Terhadap Prestasi Belajar Ilmu Pengetahuan Sosial Di Sekolah Dasar. Jurnal Cakrawala Pendas, 2(2)

Suranto, S. (2015). Pengaruh motivasi, suasana lingkungan dan sarana prasarana belajar terhadap prestasi belajar siswa (studi kasus pada sma khusus putri sma islam diponegoro surakarta). Jurnal Pendidikan Ilmu Sosial, 25(2), 11-19 